\title{
Self-efficacy and Motivation among Iranian EFL Learners: An Investigation into their Relationships
}

\author{
Azar Hosseini Fatemi (Ph.D.) \\ English Department, Ferdowsi University of Mashhad, PO box 91779-48974, Park Square \\ Ferdowsi University of Mashhad, Iran \\ E-mail: hfatemi@ferdowsi.um.ac.ir \\ Fatemeh Vahidnia (M.A.) (Corresponding author) \\ English Department, Ferdowsi University of Mashhad, PO box 91779-48974, Park Square \\ Ferdowsi University of Mashhad, Iran \\ E-mail: fateme.vahidnia@yahoo.com
}

Received: May1, 2013 Accepted: May 28, 2013 Published: April 24, 2013

doi:10.5296/ijele.v1i3.3771 URL: http://dx.doi.org/10.5296/ijele.v1i3.3771

\begin{abstract}
This paper reports on the association between Iranian EFL learners' motivation and self-efficacy. Three measures, English self-efficacy, General self-efficacy, and Language Learning Orientations, were used in this study. The participants were 93 male and female EFL learners from four different universities in Mashhad, who were at graduate (MA) and undergraduate (BA) levels. The results revealed that there exists a significant association between EFL learners' self-efficacy and their intrinsic motivation. Moreover, amotivation, among the subscales of motivation, was found to be negatively related to students' self-efficacy. Finally, the results were discussed and pedagogical implications were provided in the context of language learning and teaching.
\end{abstract}

Keywords: English self-efficacy, Motivation, General self-efficacy, EFL learners, Amotivation, Intrinsic motivation 


\section{Introduction}

It goes without saying that the constructs of "motivation" and "self-efficacy" have always been emphasized in academic setting. Owing to this fact, psychologists and educators have long considered motivation and self-efficacy as predictors of student achievement and learning which in turn contribute considerably to students' performance (Graham \& Weiner, 1996; Bandura \& Locke, 2003; Pajares, 1996).

Most researchers considered motivation as crucial element in students' learning. Graham and Weiner (1996) defined motivation as "the study of why people think and behave as they do"(p. 63). Along the same line, motivation was defined by Pintrich and Schunk (2002) as the process whereby goal directed activity is initiated and maintained. To be precise, based on the authors' definition, motivation can be understood through the task an individual selects, the effort one exerts upon these tasks though this process cannot be observed directly. In otherwords, motivation is usually defined as students' enthusiasm or desire to invest effort in engagement and persistence regarding the task (Wolters, 1998).Consequently, a highly motivated student in a course will tend to be more successful.

Of all cognitive and other personal factors affecting behavior, Bandura $(1977,1986)$ stated that self-efficacy, a factor related to motivation, is the most dominant mediator in human functioning. Bandura defined self-efficacy as "people's judgments of their capabilities to organize and execute courses of action required to attain designated types of performances" (1986, p. 391).Self-efficacy is not a general belief about self-concept or self-esteem, instead is a construct supposed to be situated, contextualized, and task-specific (Linnenbrink \& Pintrich, 2002). Based onself-efficacy theory, individual's efficacy beliefs influence the way an individual feels, thinks, motivates himself, and behaves.

\section{Literature Review}

Self-efficacy is regarded as an important variable having a strong effect on motivation. Causal tests demonstrated consistent findings concerning the significant contribution of efficacy beliefs to motivation and achievements (Bandura, 1995). Self-efficacy, as a key element of social cognitive theory, plays a primary role in students' learning, due to influencing students' motivation and learning. (Pajares, 1996, 2006; Schunk, 1995, 2003). Therefore, it is not surprising that extensive research has proved that the beliefs students have about their success or failure play a powerful role in their academic motivation, learning and subsequent academic performance (see Pajares \& Schunk, 2005).On the other hand, motivation is assumed to have an effect on self-efficacy (Bandura 1993; Henk and Melnick 1998; Jinks and Morgan 1999; Pajares and Schunk 2001; Pintrich and Schunk 2002; Schunk and Rice 1993; Schunk and Zimmerman 1997; Zimmerman 2000b; Zimmerman and Martinez-Pons 1990).

Self-efficacy theory postulates that students who judge themselves as capable and confidenttend more to be motivated; those who doubt their capabilities are not about to be motivated (Seitfert, 2004). In the light of evidence, self-efficacy and motivation can be transferred in academic domains but the transfer normally has been restricted to 
generalization. Copious research reveals that self-efficacy affects academic motivation and learning achievement (Pajares, 1996; Shunk, 1995).

Quite many studies have been carried out on the relationship between motivation and self-efficacy, and nearly all have shown that the two constructs are really reciprocally related. To put another way, motivation also serves as an essential factor in enhancing efficacy levels and teachers should focus upon it when they try to raise student efficacy levels. As a matter of fact, Linnenbrink and Pintrich (2003) affirmed that teachers feel concern for students' motivation because sentiments and beliefs about interest and worth help students to be more engaged, leading to a higher quality of experience and learning. Accordingly, in the case of being motivated in a positive way, students will tend to be more inclined to take initiative to make positive choices, thus engaging students in a cycle of hard work and success.

Several scholars, with regard to the close relationship between motivation and self-efficacy, ascertained that the expectations of academic self-efficacy influence motivation through the process of self-regulation, including goal setting, self-assessment, self-monitoring and choice of strategies (Zimmerman, 2000; Zimmerman \& Bandura, 1994; Zimmerman \& Martinez-Pons, 1990). Self-efficacy beliefs also play as underlying and vital factors in the regulation of motivation (e.g. Schunk \& Ertmer, 2000).Hence, it is imperativeto analyze variables related to the self in the study of motivation for learning. These variables include how students observe themselves in the future through their goals, their beliefs concerning their own competencies and the value they attributed to tasks.

In this line of inquiry, a number ofscholars delved into the effect of students' self-efficacy on motivation and learning (Bouffard-Bouchard, 1990; Bouffard-Bouchard, Parent, \& Larivée, 1991; Lent, Brown, \& Hackett, 2002; Linnenbrink \& Pintrich, 2003; Pintrich \& De Groot, 1990; Schunk, 2003; Zimmerman, Bandura, \& Martinez-Pons, 1992). Their findings exhibit that self-efficacy has a strong effect on motivation and cognition through influencing students' task persistence, task interest, the goals they set, the choices they make and their use of cognitive, meta-cognitive and self-regulatory strategies.

A great deal of research has been carried out to highlight the predicting and mediating role of self-efficacy in relation to students' achievements, motivation and learning. Likewise, Collins (1982) proved that self-efficacy plays a predicting role in motivation and achievement across levels of student ability. Children labeled as high, average, or low in mathematical ability, were grouped in high or low regarding efficacy for solving word problems. Students were presented with problems to solve (some were insolvable) and had the chance to rework any they missed. The results showed that Low- and average-ability students with high efficacy tackled with insolvable problems longer than did low-efficacy students. Students with higher efficacy reworked more problems irrespective of ability than did students with lower efficacy. In a similar vein, Pintrich and De Groot (1990) and Zimmerman and Martinez-Pons (1990) confirm the proposed positive relations among motivation, efficacy, and strategy use (Como, 1989; Schunk, 1989b).

To summarize thus far, self-efficacy beliefs plays a crucial role in motivation and achievements in a number of ways: they determine the goals people set for themselves, how 
much effort they exert, how long they persevere when faced with obstacles and their resilience in the face of failures ( Bandura, 1995). People who judge themselves as incapable will lower their efforts or give up quickly in the face of difficulties and failures. On the other hand, those who have a deep faith in their capabilities invest more considerable effort when they fail to overcome a challenge.

Hitherto, the reoccurring theme in the bulk of foregoing articles and studies is the relationship between students' self-efficacy and their motivation. However, this connection within an EFL context of Iran had remained somehow untouched. The correlation between Iranian EFL learners' self-efficacy and motivation is not necessarily disputed; however, testing the concept of self-efficacy relative to academic motivation (Graham \& Weiner, 1996) has been at the center of many self-efficacy studies carried out so far. Therefore, paucity of research in this realm within an EFL context of Iran makes this particular study significant, with the chief purpose of discerning whether there is a significant association between learners' motivation and their self-efficacy or not. By taking the role of motivation and self-efficacy in students' learning into account, this paper, thus, mainly centers on determining this relationship. Hence, following research questions will be addressed in the present study: 1) Is there any relationship between Iranian learners' English self-efficacy and their motivation? 2) Is there any association between Iranian students' General self-efficacy and their motivation?

\section{Methodology}

\subsection{Setting and Participants}

The participants of this study consisted of 93 EFL learners (38 males and 55 females) from different universities, i.e. Ferdowsi University, Imam Reza University, Tabaran and Khayyam in Mashhad, Iran. Learners were upper-intermediate students whose age ranged from 20 to 30. It should be noted that all the students who participated in this study had majored in the various branches of English, such as English Teaching as a Foreign Language, English Literature, or English Translation. The participants were undergraduate $(\mathrm{BA}=55)$ and graduate $(\mathrm{MA}=38)$ students; it's worth mentioning that the graduate students were all from Ferdowsi University of Mashhad.

\subsection{Instrumentation}

The questionnaires employed in this study to measure students' self-efficacy and motivation are as follows:

Language Learning Orientations Scale. Language Learning Orientations Scale designed by Noels et al. (2000) was employed to measure students' motivation. It consists of twenty one items on a seven point scale to assess three subcomponents of intrinsic and extrinsic motivation and amotivation. Running Cronbach's alpha, the reliability of this scale for the present study was .87.

General Self-Efficacy Scale. To measure students' general self-efficacy the researchers used the General Self-Efficacy Scale (GSES), designed and validated by Sherer et al., (1982). This scale includes 17 items. Each item recipes a score of 1 to 5producing a score range of 17 to 
85.In the current study, Cronbach's alpha for this scale was 0.89 .

English Self-Efficacy Scale. To assess students' English self-efficacy the researchers used the English Self-Efficacy Scale (ESES), developed and validated by Rahemi., (2001). It consists of 10 items using a five-point Likert scale ranging from 'strongly disagree' (one) to 'strongly agree' (five). The total reliability of the scale in the current study, estimated via Cronbach's alpha, was 0.83 .

\subsection{Procedure}

The process of data collection started in May, 2012 and continued until July, 2012. The researchers talked to seven university professors and sought their permission for interrupting their classes and testing students. All of them permitted researchers to use their class time. The questionnaires were administered to the language learners to assess their self-efficacy and motivation.

For the purpose of analyzing the data, they were given to the SPSS 16 program. In order to explore the association between English self-efficacy and motivation, Pearson correlation was run. Another Pearson correlation was used to examine the relationship between General self-efficacy and motivation.

\section{Results}

The first research question was whether there was a relationship between English self-efficacy and motivation. Table 1 depicts the results of the correlational analysis.

Table 1. The Relationship between English Self-Efficacy and Motivation

\begin{tabular}{lccc}
\hline Motivation & Intrinsic & Extrinsic & Amotivation \\
\hline English Self-Efficacy & $.39 *$ & $.19-$ & $.49 * *$ \\
\hline
\end{tabular}

$* \mathrm{p}<.05, * * \mathrm{p}<.01$

As may be observed in Table 1, English Self-Efficacywas significantly and positively associated with Intrinsic Motivation ( $\mathrm{r}=.39, \mathrm{p}<.05)$. No significant relationship was found between English Self-Efficacy and Extrinsic Motivation $(\mathrm{r}=.19)$. Significant and negative relationship was found, confirming the general expectation that amotivation would be negatively related to English Self-Efficacy $(r=-.49, p<.01)$.It is interesting to note that amotivation has the highest correlation coefficient with English Self-Efficacy; however, Intrinsic Motivation was the second variable which positively associated with English Self-Efficacy.

To answer the second research question, Pearson correlations were run to figure out the potential relationships between learners' General Self-Efficacy and subscales of Motivation. 
The results of correlations can be observed in Table 2 .

Table 2. The Relationship between General Self-Efficacy and Motivation

\begin{tabular}{lccc}
\hline Motivation & Intrinsic & Extrinsic & Amotivation \\
\hline General Self-Efficacy $.29^{* *}$ & .12 & $-.36^{* *}$ \\
\hline
\end{tabular}

$* \mathrm{p}<.05, * * \mathrm{p}<.01$

Based on Table 2, there exists meaningful and positive association between General self-efficacy and intrinsic motivation $(r=.29, \mathrm{p}<.01)$. As expected before, General self-efficacy is negatively and significantly related to amtivation $(\mathrm{r}=-.29, \mathrm{p}<.01)$. In accordance with English self-efficacy, General self-efficacy did not show any significant relationship with extrinsic motivation.

Up to this point it can be deduced that both English self-efficacy and General self-efficacy revealed the same findings with minute differences in the amount of rregarding their associations with subscales of motivation. As compared to English self-efficacy, General self-efficacy exhibited lower correlations with regard to subscales of motivation.

\section{Discussion and Conclusion}

The goal of this study was to address gaps in the literature on motivation and self-efficacy in an EFL context by examining the relationship between Iranian students' motivation and self-efficacy beliefs in an EFL environment. As regards the first and second research questions, we came up with the conclusion that English and General Self-Efficacy are significantly and positively related to Intrinsic Motivation, one of the subscales of motivation. In addition, no significant relationship was found between English and General Self-Efficacy with Extrinsic Motivation. As expected before, English and General Self-Efficacy were found to be associated significantly and negatively with amotivation.

The results suggest that those Iranian EFL learners who wish to engage in an activity just for the sake of the activity and without any expectation of the reward, find themselves more efficacious in performing the activity. To say, holding higher intrinsic motivation to engage in the activity was associated with higher levels English and General Self-Efficacy in that specific activity.

As it was mentioned in the literature review, motivation can be understood through the task an individual selects, the effort one exerts upon these tasks although is a process which cannot be observed directly (Pintrich \& Schunk, 2002). Furthermore, self-efficacy theory postulates that students who judge themselves as capable and confident tend more to be motivated (Seitfert, 2004). 
This result confirms causal tests which demonstrated consistent findings concerning the significant contribution of efficacy beliefs to motivation (Bandura, 1995). To put another way, the two constructs are really reciprocally related. The obtained finding is also in line with copious research which demonstrated that self-efficacy plays a powerful role in students' learning and motivation and thus is of prime importance regarding academic motivation (Bandura 1993; Henk \& Melnick 1998; Jinks \& Morgan 1999; Pajares \& Schunk 2001; Pajares, 1996, 2006; Pajares \& Schunk 2005; Pintrich \& Schunk 2002; Schunk, 1995, 2003; Schunk \& Rice 1993; Schunk \& Zimmerman 1997; Zimmerman 2000b; Zimmerman \& Martinez-Pons 1990). Moreover, our finding lends support to a number of studies which delved into the effect of students' self-efficacy on motivation and learning (Bouffard-Bouchard, 1990; Bouffard-Bouchard, Parent, \& Larivée, 1991; Lent, Brown, \& Hackett, 2002; Linnenbrink \& Pintrich, 2003; Pintrich \& De Groot, 1990; Schunk, 2003; Zimmerman, Bandura, \& Martinez-Pons, 1992). Their findings demonstrate that self-efficacy has a strong effect on motivation and cognition through influencing students' task persistence, task interest, the goals they set, the choices they make and their use of cognitive, meta-cognitive and self-regulatory strategies.

Our result regarding intrinsic motivation and self-efficacy can be interpreted in the light of characteristics of intrinsically motivated and self-efficient individuals. Intrinsically motivated individuals show greater persistence, perform at high levels and invest much effort in learning and use a deep level of processing while learning (Deci \& Ryan, 1985; Pokay \& Blumenfeld, 1990; Vansteenkiste, Lens, \& Deci, 2006). They freely choose to perform an activity, they will look for situations in which they can meet the challenges that the activity offers and to develop a sense of competence in their abilities (Deci and Ryan, 1985). Likewise, self-efficient learners set high goals for themselves, exert much effort, persist longer when faced with obstacles, have great interest in the task and show resilience in the face of failures (Bandura, 1995). Based on the aforementioned features, it can be concluded that intrinsically motivated learners have some characteristics in common with self-efficient ones. Therefore, it is obvious that those Iranian EFL learners who had higher intrinsic motivation, enjoyed higher self-efficacy which seems quite plausible concerning their similar characteristics.

In contrast, those Iranian EFL learners who find neither intrinsic nor extrinsic motivation for performing the activity, have low level of self-Efficacy. This would mean that those learners who had the impression that they were wasting their time studying the L2 (Ryan and Deci 2000), showed low level of English and General Self-Efficacy. The reason for this result may be the fact that amotivated learners think that they are wasting their time studying the L2. They do not value language learning, do not persist, do not consider themselves as capable in doing it or do not have expectation for being successful (Ryan and Deci 2000). Furthermore, they are not expected to exert much effort in performing an activity, and would likely to quit as soon as it as feasible to do so (Noels, 2001) as opposed to self-efficient learners who persist longer, exert much effort and feel competent in doing the task.

To sum up, those Iranian EFL learners who needed no external coercion to engage in an activity, hold higher level of General and English self-Efficacy than those who undertake the 
activity merely to attain rewards. Conversely, those learners who believe there is no link between their actions and its consequences, rather view factors outside of their controls as the cause of what happens to them hold low level of General and English self-Efficacy. Since, they are not expected to exert much effort in performing an activity, and would likely quit as soon as it is feasible to do so, they are less efficacious. Hence, the drawn conclusion is completed in this way: No matter what kind of self-efficacy questionnaire is used in the study, Iranian EFL learners tend to be self-efficacious if they are intrinsically motivated; high levels of intrinsic motivation can be equated with holding high levels of self-efficacy.

The findings of the current study have a number of educational implications. This study documents the importance of motivation and self-efficacy as they pertain to EFL students' acquisition of L2. Second, the present research points out that educators need to be cognizant of and attend to the changes in students' efficacy beliefs and motivation to learn English as they progress through courses. Third, teaching students strategies to improve their efficacy beliefs and their level of motivation can enable them to know what to do to succeed at an academic task and to perform well. Moreover, it is imperative that teachers develop and sustain their students' self-efficacy for learning. Research shows that self-efficacy and achievement can be enhanced through instructional methods that incorporate modeled strategies, progress feedback, goal setting, and self-evaluations of progress. To the extent that these and other efficacy-enhancing methods are employed in classrooms, teachers will foster academic achievement and motivation for continued learning among all learners.

Thereby, we want to acknowledge that like all studies, ours had several limitations, of which we describe some. Our sample consisted just of university students of Mashhad, Iran. Another hindrance is that, this study did not take other levels of education such as high school, into account. Therefore, it is recommended that future research be conducted including students of other cities and from different levels. Further research is also needed to understand the influences that may be affecting the self-efficacy and motivation of learners, such as gender, level and goal choice. Although a great deal of research has already been conducted on students' motivation in academic settings (elementary through college), there is a clear need for additional research. In addition, although the current theories of motivation are social cognitive and emphasize both individual and contextual influences, much of the research within achievement motivation has focused on motivation at the individual level. Educational researchers are urged to further examine how specific features of the classroom environment might affect a variety of aspects of students' motivation.

\section{References}

Bandura, A. (1977). Social learning theory. Englewood Cliffs, NJ: Prentice-Hall.

Bandura, A. (1986). Social foundations of thought and action: A social cognitive theory. Englewood Cliffs, NJ: Prentice Hall. p. 391.

Bandura, A. (1993). Perceived self-efficacy in cognitive development and functioning. Educational Psychologist, 28(2), 117-48.

Bandura, A. (1995). Self-Efficacy in Changing Societies. New York, NY: Cambridge 
University Press.

Bandura, A., \& Locke, E.A. (2003). Negative self-efficacy and goal effect revisited. Journal of Applied Psychology, 88, 87-99. http://dx.doi.org/ 10.1037/0021-9010.88.1.87

Bouffard-Bouchard, T. (1990). Influence of self-efficacy on performance in a cognitive task. TheJournal of Cognitive Psychology, 130(3), 353-363.

Bouffard-Bouchard, T., Parent, S., \& Larivée, S. (1991). Influence of self-efficacy on self-regulation and performance among junior and senior high-school age students. International Journal of Behavioral Development, 14(2), 153-164. http://dx.doi.org /10.1177/016502549101400203

Collins, J. (1982, March). Self-efficacy and ability in achievement behavior. Paper presented at the meeting of the American Educational Research Association, New York.

Corno, L. (1989). Self-regulated learning: A volitional analysis. In B. J. Zimmerman \& D. H. Schunk (Eds.), Self-regulated learning and academic achievement: Theory, research, and practice (pp. 111-141). New York: Springer-Verlag.

Deci, E. L., \& Ryan, R. M. (1985).Intrinsic motivation and self-determination in human behavior. New York, NY: Plenum Press.

Graham, S., \& Weiner, B. (1996). Theories and principles of motivation. In D. C. Berliner \& R. Calfee (Eds.), Handbook of educational psychology (pp. 63-84). New York: Macmillan.

Henk, W. A., \&. Melnick.S. A (1998). Upper elementary-aged children's reported perceptionsabout good readers: A self-efficacy influenced update in transitional literacy contexts. Reading Research and Instruction, 38(1), 57-80.

Jinks, J., \& Morgan.V. (1999).Children's perceived academic self-efficacy: An inventory scale. The Clearing House, 72(4), 224-30.

Lent, R. W., Brown, S. D., \& Hackett, G. (2002).Social cognitive career theory. In D. Brown (Ed.), Career choice and development (pp. 255-311). San Francisco: Jossey-Bass.

Linnenbrink, E. A., \& Pintrich, P. R. (2002).Motivation as an enabler for academic success. School Psychology Review, 31(3), 313-327.

Linnenbrink, E. A., \& Pintrich. P. R. (2003). The role of self-efficacy beliefs in student engagement and learning in the classroom. Readingand Writing Quarterly: Overcoming Learning Difficulties, 19(2), 119-138.

Noels, K. A., Pelletier, L. G., Cle'ment, R., \& Vallerand.R. (2000). Why are you learning a second language? Motivational orientations and self-determination theory. Language Learning, 50, 57-85.

Noels, K. A. (2001). Learning Spanish as a second language: Learners' Orientations and Perceptions of Their Teachers' Communication Style. Language Learning, 51(1), 107-144.

Pajares, F. (1996). Self-Efficacy Beliefs in Academic Settings. Review of Educational 
Research, 66(4), 543-578. http://dx.doi.org/10.3102/00346543066004543

Pajares, F., \&. Schunk.D. H (2001). Self-beliefs and school success: Self-efficacy, self-concept, and school achievement. In Perception, 239-66., ed. R. Riding and S. Rayner. London: Ablex Publishing.

Pajares, F., \& Schunk, D. H. (2005). Self-efficacy and self-concept beliefs: Jointly contributing to the quality of human life. In H. Marsh, R. Craven, \& D. McInerney (Eds.), International advances in self-research (Vol. 2, pp. 95-121). Greenwich, CT: Information Age Publishing.

Pintrich, P., \& De Groot, E. (1990).Motivational and self-regulated learning, components of classroom academic performance.Journal of Educational Psychology, 82, 33-40. http://dx.doi.org/10.1037/0022-0663.82.1.33

Pintrich, P. R., \& Schunk. D. H. (2002). Motivation in education: Theory, research, and applications (2nd ed.). Englewood Cliffs, NJ: Prentice Hall.

Pajares, F. (2006). Self-efficacy during childhood and adolescence: Implications for teachers and parents. In F. Pajares, \& T. Urdan (Eds.), Self-efficacy beliefs of adolescents (pp. 339-367). Greenwich, CT: Information Age Publishing.

Pokay, P., \& Blumenfeld, P. C. (1990).Predicting achievement early and late in the semester: The role of motivation and use of learning strategies. Journal of Educational Psychology, 82, $41-50$.

Rahemi, J. (2001). Self-efficacy in English and Iranian senior high school students majoring in humanities. Research on Youth and Language, 1(2), 98-111.

Ryan, R. M., \& Deci. E. L. (2000). Self-determination theory and the facilitation of intrinsic motivation, social development, and wellbeing. American Psychologist, 55(1), 68-78.

Schunk, D. H. (1989). Self-efficacy and cognitive skill learning. In C. Ames \& R. Ames (Eds.), Research on motivation in education: Vol. 3. Goals and cognitions (pp. 13-44). San Diego: Academic.

Schunk, D. H., \& J. M. Rice. (1993). Strategy fading and progress feedback: Effects on self-efficacy and comprehension among students receiving remedial reading services. Journal of Special Education, 27, 257-76.

Schunk, D. H. (1995). Self-efficacy and education and instruction. In J. E. Maddux (Ed.), Self-efficacy, adaptation and adjustment: Theory, research and application (pp. 281-303). New York: Plenum Press.

Schunk, D. H., \&. Zimmerman. B. J. (1997). Developing self-efficacious readers and writers: The role of social and self-regulatory processes. In Reading engagement: Motivating readers through integrated instruction, 34-50., ed. J. T. Guthrie and A. Wigfield. Newark, DE: International Reading Association.

Schunk, D. H., \& Ertmer, P. A. (2000). Self-Regulation and academic learning: self-efficacy 
enhancing interventions. In Boeakaerts, P. R. Pintrich, \& M. Zeidner (Eds.), Handbook of self-regulation (pp.631-650). San Diego, CA: Academic Press.

Schunk, D. H. (2003). Self-efficacy for reading and writing: Influence of modeling, goal setting and self-evaluation. Reading and Writing Quarterly: Overcoming Learning Difficulties, 19(2), 159-172.

Sherer, M., Maddux, J. E., Mercandante, B., Prentice-Dunn, S., Jacobs, B. \& Rogers, R. W. (1982). The self-efficacy scale: Construction and validation. Psychological Reports, 51, 663-671.

Seitfert, T. (2004). Understanding student motivation: Educational Research, 46(2), 137-149. http://dx.doi.org/10.1080/0013188042000222421

Vansteenkiste, M., Lens, W., \& Deci, E. L. (2006). Intrinsic versus extrinsic goal contents in self-determination theory: Another look at the quality of academic motivation. EducationalPsychologist, 41(1), 19-31.

Wolters, C. A. (1998). Self-regulated learning and college students' regulation of motivation.Journal of Educational Psychology, 90, 224-235.

Zimmerman, B. J., \& Martinez-Pons, M. (1990). Student differences in self-regulated learning: Relating grade, sex, and giftedness to self-efficacy and strategy use. Journal of Educational Psychology, 82(1), 51-59.

Zimmerman, B. J., Bandura, A., \& Martinez-Pons, M. (1992). Self-motivation for academic attainment: The role of self-efficacy beliefs and personal goal setting. American EducationalJournal, 29(3), 663-676. http://dx.doi.org/10.3102/00028312029003663

Zimmerman, B. J., \& Bandura, A. (1994). Impact of self-regulatory influences on writing course attainment.American Education Research Journal, 31(4), 845-862.

Zimmerman, B. J. (2000). Attaining self-regulation: A social cognitive perspective. In M. Boekaerts, P. R. Pintrich, \& M. Zeidner (Eds.), Handbook of self-regulation (pp. 13-35). San Diego, CA: Academic Press.

\section{Copyright Disclaimer}

Copyright reserved by the author(s).

This article is an open-access article distributed under the terms and conditions of the Creative Commons Attribution license (http://creativecommons.org/licenses/by/3.0/). 